\title{
Efektivitas Dana Bantuan Operasional Sekolah (BOS) dalam Peningkatan Mutu Pendidikan pada MIN Lumpatan Kabupaten Musi Banyuasin
}

\author{
Fathullah \\ MTS Negeri 01 Musi Banyuasin \\ fathultahrim@gmail.com
}

\begin{abstract}
The School Operational Assistance (BOS) program aims to free up tuition fees for underprivileged students and provide relief for other students, so that they can get better quality basic education services until they are completed in order to complete 9 years of basic education compulsory education. Through $B O S$, the level of primary education students will be freed from all kinds of school operational costs. The purpose of this study was to find out the Management of the School Operational Assistance Fund (BOS) in improving the learning process in State MTs 1 and Al-Arkom MTs Palembang. The technical analysis used in this study is a qualitative data analysis technique. While the data collection techniques used are interviews, documentation and observation. The results showed that the effectiveness of the management of Operational Assistance funds in the process of improving the learning process in Palembang 1 MTSN had been running effectively in accordance with the 2007 School Operational Aid published by the Indonesian Ministry of Religion. As for the effective ones, namely the need for the availability of funds, facilities and infrastructure to support teaching and learning activities, buman resources, planning activities or programs and the amount of funds that will be used for these activities or programs, activities to use school operational assistance funds to meet school needs, coordination between the school and the KOMITE, oversight of the use of the School Operational Assistance Fund (BOS), the improvement of the quality of education, the achievement of the objectives of the use of BOS funds and the achievement of the main objectives of the BOS funds program. Whereas in MTS Al-Arkom, the management of BOS funds has not been implemented effectively, namely the need for the availability of funds, facilities and infrastructure to support teaching and learning activities, buman resources, planning activities or programs and the amount of funds to be used for these activities or programs. the school with the school KOMITE.
\end{abstract}

Keywords: School Operational Assistance (BOS), Learning Process.

Abstrak : Program dana Bantuan Operasional Sekolah (BOS) bertujuan untuk membebaskan biaya pendidikan bagi siswa tidak mampu dan meringankan bagi siswa yang lain, agar mereka memperoleh layanan pendidikan dasar yang lebih bermutu sampai tamat dalam rangka penuntasan wajib belajar pendidikan dasar (Wajar Diknas) 9 tahun. Melalui BOS peserta didik tingkat pendidikan dasar akan dibebaskan dari segala macam bentuk biaya operasional sekolah. Tujuan Penelitian ini adalah untuk. mengetabui Pengelolaan Dana Bantuan Operasional Sekolah (BOS) dalam meningkatkan proses pembelajaran di MTs Negeri 1 dan MTs Al-Arkom Palembang. Teknis analisis yang digunakan dalam penelitian ini adalah teknik analisis data kualitatif. Sedangkan Teknik pengumpulan data yang digunakan yaitu wawancara, dokumentasi dan observasi. Hasil penelitian menunjukean babwa Efektivitas pengelolaan dana Bantuan Operasional dalam proses peningkatan proses pembelajaran pada MTSN 1 Palembang telah berjalan dengan efektif sesuai dengan buku pedoman Bantuan Operasional Sekolah terbitan Departemen agama RI tabun 2007. Adapun yang efektif yaitu, Kebutuban akan tersedianya dana, sarana dan prasarana penunjang kegiatan belajar mengajar, Sumber daya manusia, Perencanaan kegiatan atau program dan besarnya dana yang akan digunakan untuk kegiatran atau program tersebut, kegiatan penggunaan dana bantuan operasional sekolah dalam memenubi kebutuban sekolah, Koordinasi antara pihak sekolah dengan KOMITE, pengawasan terhadap penggunaan dana Bantuan Operasional Sekolah (BOS), Peningkatan mutu pendidikan, Tercapainya tujuan penggunaan dana BOS serta Tercapainya Tujuan Utama Program dana BOS. Sedangkan pada MTS Al-Arkom, pengelolaan dana BOS belum dilaksanakan dengan efektif yaitu Kebutuban akan tersedianya dana, sarana dan prasarana penunjang kegiatan belajar mengajar, Sumber daya manusia, Perencanaan kegiatan atau program dan besarnya dana yang akan digunakan untuk kegiatran atau program tersebut, Koordinasi antara pibak sekolah dengan KOMITE sekolah.

Kata Kunci : Bantuan Operasional Sekolah (BOS), Proses Pembelajaran 


\section{Pendahuluan}

Kebijakan pembangunan pendidikan dalam kurun waktu 2004-2009 meliputi peningkatan akses rakyat terhadap pendidikan yang lebih berkualitas melalui peningkatan pelaksanaan wajib belajar pendidikan dasar 9 tahun dan pemberian akses yang lebih besar kepada kelompok masyarakat yang selama ini kurang dapat menjangkau layanan pendidikan.

Salah satu permasalahan dalam penuntasan program wajib belajar 9 tahun antara lain mencakup masalah kependidikan, fasilitas, manajemen, proses pembelajaranm mutu pendidikan dan prestasi siswa (dalam Panduan Bantuan Operasional Sekolah Dalam Rangka Wajib Belajar 9 Tahun 2006). Berdasarkan hal tersebut, jelas sekali bahwa mutu pendidikan merupakan salah satu permasalahan dalam penuntasan program wajib belajar 9 tahun. Adapun data mengenai ruang pendidikan dan kondisinya, di Madrasah Ibtidayah Negeri Lumpatan Kabupaten Musi Banyuasin yang mendapatkan dana Bantuan Operasional Sekolah (BOS) di Kabupaten Musi Banyuasin, dapat dilihat pada tabel 1:

\section{Tabel 1}

Data Ruang Pendidikan dan Kondisinya Tahun 2009

\begin{tabular}{|c|c|c|c|c|c|c|}
\hline \multirow{2}{*}{ No } & \multirow{2}{*}{ Nama Ruang } & \multirow{2}{*}{$\begin{array}{c}\text { Rincian } \\
\text { Ruang }\end{array}$} & \multicolumn{3}{|c|}{ Kondisi Ruang } & \multirow{2}{*}{ Ket } \\
\hline & & & Baik & Sedang & Rusak & \\
\hline 1. & Kelas & 14 & $\mathrm{~V}$ & & $\mathrm{~V}$ & 11 (baik), 3 (rusak) \\
\hline 2. & Ruang guru & 1 & $\mathrm{~V}$ & & & \\
\hline 3. & Perpustakaan & 1 & $\mathrm{~V}$ & & & \\
\hline 4. & Ruang Kepala Sekolah & 1 & $\mathrm{~V}$ & & & \\
\hline 5. & Lapangan & 1 & V & & & \\
\hline 6. & Ruang UKS & 1 & & $\mathrm{~V}$ & & \\
\hline
\end{tabular}

Sumber: Kantor Tata Usaha Madrasah Ibtidayah Negeri Lumpatan Kabupaten Musi Banyuasin tahun 2009

Berdasarkan tabel tersebut dapat dilihat bahwa kondisi masing-masing ruang dan sarana pendidikan di Madrasah Ibtidayah Negeri Lumpatan Kabupaten Musi Banyuasin, semua kondisinya baik hanya ruang UKS dengan kondisi sedang dan ruang kelas masih ada yang berkondisi rusak. Hal ini menunjukkan bahwa adanya ketidaksesuaian antara dana BOS yang dikeluarkan dengan kondisi saat ini, sebab dalam BOS terdapat alokasi dana perawatan/pemeliharaan. Kondisi ini dikhawatirkan dapat menghambat dalam peningkatan mutu pendidikan di sekolah.

Berdasarkan kebijakan pembangunan pendidikan tahun 2004-2009 yang meliputi peningkatan akses terhadap pendidikan yang lebih berkualitas melalui peningkatan wajib belajar pendidikan dasar 9 tahun dan pemberian akses yang lebih besar kepada kelompok masyarakat yang kurang dapat menjangkau layanan pendidikan. Pemerintah kemudian mengadakan PKPS-BBM.

Dengan adanya pengurangan subsidi bahan bakar minyak, amanat Undang-undang dan upaya percepatan wajib belajar pendidikan dasar 9 tahun 
yang bermutu, pemerintah melanjutkan pemberian dana Bantuan Operasional Sekolah (BOS) bagi SD/MI/SDLB/SMP/MTs/SMPLB negeri/swasta dan Pesantren Salafiyah serta sekolah keagamaan non islam setara SD dan SMP yang menyelenggarakan wajib belajar pendidikan dasar 9 tahun.

Tabel 2

Alokasi Dana Bantuan Operasional Sekolah (BOS) Kabupaten Musi Banyuasin Tahun 2009

\begin{tabular}{|c|c|c|c|}
\hline \multirow{2}{*}{$\begin{array}{c}\text { Jenjang } \\
\text { Sekolah }\end{array}$} & \multicolumn{3}{|c|}{ Sasaran dan Unit Cost } \\
\cline { 2 - 4 } & Siswa & Rp/Siswa & Total Dana \\
\hline $\begin{array}{c}\text { MIN Lumpatan } \\
\text { Kabupaten } \\
\text { Banyuasin }\end{array}$ & 330 & $99.250 / 3 \mathrm{bulan}$ & $125.065 .000,-$ \\
\hline
\end{tabular}

Sumber: tahun 2009 MIN Lumpatan Kabupaten Banyuasin

Berdasarkan Tabel 2 dapat dilihat bahwa alokasi yang diberikan kepada tiap jenjang pendidikan berbeda-beda, disesuaikan dengan jenis sekolah itu sendiri, antara MI, MTs, dan Ponpes mendapat dana yang berbeda. Sumber dana tersebut berasal dari pengalihan sebagian dari subsidi Bahan Bakar Minyak (BBM) yang termasuk dalam Anggaran Pendapatan dan Belanja Negara (APBN). Dana APBN yang diberikan dalam jumlah yang besar tersebut tentunya harus dikelola dengan baik karena apabila tidak demikian tentunya akan menimbulkan penyelewengan-penyelewengan dalam pengelolaan dana tersebut.

Bantuan Operasional Sekolah (BOS) harus menjadi salah satu sumber pembiayaan dalam Rencana Anggaran Pendapatan dan Belanja Sekolah (RAPBS). Bantuan Operasional Sekolah (BOS) sendiri pada dasarnya hanya boleh digunakan oleh sekolah sesuai dengan kebutuhan operasional sekolah. Sebagaimana telah diatur dalam Buku Panduan Bantuan Operasional Sekolah Dalam Rangka Wajib Belajar 9 Tahun 2009, yang menyebutkan bahwa dana Bantuan Operasional Sekolah (BOS) digunakan untuk:

a. Pembiayaan seluruh kegiatan dalam rangka penerimaan siawa baru: biaya pendaftaran, pengadaan formulir, administrasi pendaftaran, dan pendaftaran ulang, serta kegiatan lain yang berkaitan langsung dengan kegiatan tersebut.

b. Pembelian buku teks pelajaran (diluar buku yang telah dibeli dari dana BOS buku) dan buku referensi untuk dikoleksi di perpustakaan.

c. Pembiayaan kegiatan pembelajaran remedial, pembelajaran pengayaan, olahraga, kesenian, karya ilmiah remaja, pramuka, palang merah remaja dan sejenisnya.

d. Pembiayaan ulangan harian, ulangan umum, ujian sekolah/madrasah/ponpes dan laporan hasil belajar siswa

e. Pembelian bahan-bahan habis pakai 
f. Pembiayaan langganan daya dan jasa

g. Pembiayaan perawatan sekolah/madrasah/ponpes:pengecetan; perbaikan atap bocor; perbaikan pintu dan jendela; perbaikan meubeler, perbaikan sanitasi sekolah dan perawatan fasilitas sekolah lainnya.

h. Pembayaran honorarium bulanan guru honorer dan tenaga kependidikan honorer.

i. Pengembangan profesi guru; pelatihan, KKG/MGMP dan KKKS/MKKS

j. Pemberian bantuan biaya transportasi bagi siswa miskin yang menghadapi masalah biaya transport dari dan ke sekolah/madrasah/ponpes

k. Pembiayaan pengelolaan BOS

1. Khusus untuk pesantren salafiyah dan sekolah keagamaan/non islam, dana BOS dapat digunakan untuk biaya asrama/pondokan dan membeli peralatan ibadah.

m. Apabila terdapat sisa dana, maka dapat digunakan untuk membeli alat peraga, media pembelajaran dan meubeler sekolah.madrasah/ponpes.

Berdasarkan hasil Monitoring dan evaluasi yang telah dilakukan (Laporan Kegiatan PKPS-BBM Bidang Pendidikan Tahun 2008) pemanfaatan dana BOS sangat bervariasi, tergantung kebutuhan sekolah. Dana yang diterima dimanfaatkan sesuai dengan jenis yang ada di Buku Panduan BOS. Persentase pemanfaatan setiap pos sekolah sangan bervariasi antar sekolah. Perbedaan ini sering kali disikapi kepala sekolah sebagai suatu kesulitan, karena buku panduan BOS tidak memberikan petunjuk pagu anggaran masing-masing pos pengeluaran.

Berdasarkan notisi audit dan tanggapan lampiran exit conference audit dana BOS tahun 2008, terdapat beberapa permasalahan-permasalahan dari pelaksanaan penggunaan dana BOS untuk Madrasah Ibtidayah Negeri Lumpatan Kabupaten Musi Banyuasin pada tahun anggaran 2007/2008. Permasalahan tersebut adalah sebagai berikut

1. Dana yang diterima kurang sesuai dengan jumlah siswa yang ada

2. Keterbatasan kemampuan dan keterampilan kepala sekolah dalam hal adminitrasi keuangan dan perpajakan

3. Keterbatasan dana untuk melaksanakan program peningkatan mutu pendidikan seperti peralatan laboratorium, pembelian komputer, perbaikan ruang kelas, ruang laboratorium dan ruang perpustakaan

Mengingat dana BOS berasal dari anggaran pemerintah dan merupakan salah satu kebijakan keuangan pemerintah dibidang pendidikan untuk masyarakat, masyarakat berhak untuk mendapatkan kejelasan, kejujuran dari penggunaan dana bantuan tersebut sebagai salah satu kontrol bentuk sosial masyarakat dalam meningkatkan mutu pendidikan. Oleh Karena itu penulis tertarik untuk menganalisis bagaimana efektivitas penggunaan Dana Bantuan 
Operasional Sekolah (BOS) dalam meningkatkan mutu pendidikan di Madrasah Ibtidayah Negeri Lumpatan Kabupaten Musi Banyuasin

\section{Landasan Teori}

Menurut Uma Sekaran dalam bukunya Business Research (Sugiyono, 2003:65), mengemukakan bahwa kerangka pemikiran merupakan model konseptual tentang bagaimana teori berhubungan dengan berbagai faktor yang telah diidentifikasi sebagai masalah yang penting. Kerangka berpikir yang baik akan menjelaskan secara teoretis pertautan antarvariabel yang akan diteliti. Pada bagian ini penulis akan menguraikan secara teoretis mengenai efektifitas, pengelolaan Dana BOS.

\section{Efektivitas}

Keberlangsungan organisasi sangat dipengaruhi oleh berbagai faktor, baik dari sisi internal organisasi tersebut, namun juga dari sisi eksternal yaitu lingkungan yang berada di sekitar organisasi. Dengan kata lain, akan ada sebuah proses integrasi antar sub-sub dalam organisasi serta dipengaruhi oleh lingkungan sekitarnya.

Keberhasilan suatu organisasi dalam menjaga keberlangsungannya biasanya akan selalu dikaitkan dengan bagaimana suatu organisasi secara keseluruhan mencapai tujuan yang telah ditetapkan. Salah satu cara yang paling banyak digunakan untuk mengukur tingkat keberhasilan suatu organisasi yaitu pengukuran efektivitas.

Sesuai dengan teori yang paling sederhana yang berpendapat bahwa efektivitas organisasi sama dengan prestasi organisasi secara keseluruhan (Munir, dkk., 2004: 59). Keseluruhan tersebut dalam arti setiap tingkatan sub-sub yang terdapat dalam organisasi yang bersangkutan, dituntut untuk melakukan setiap pekerjaan semaksimal dan seoptimal mungkin serta memiliki ketetapan pada penyelesaiannya dan mempunyai daya dukung terhadap setiap pekerjaan.

Stephen P. Robbins (dalam Rukmana, 2006:15) mendefinisikan efektivitas sebagai perwujudan dari tujuan-tujuan organisasi. Adapun kriteria pencapaian tujuan tersebut adalah efektif dan efisien. Menurut Mulin, L.J (Rukmana, 2006:15), menegaskan bahwa efektif itu terkait dengan produk atau output, efektif fokusnya pada mengerjakan sesuatu hal yang benar, sedangkan efisien terkait dengan input dan bagaimana kita mengerjakannya dengan baik dan benar. Oleh karena itu, Mullin berpendapat bahwa efektif itu harus terkait dengan pencapaian tujuan dan sasaran suatu tugas atau pekerjaan, dan terkait juga dengan kinerja dari proses pelaksanaan suatu pekerjaan

Selain itu menurut Steers, efektivitas itu sendiri paling baik dapat dimengerti jika dilihat dari sudut sejauh mana organisasi berhasil mendapatkan dan memanfaatkan sumber daya dalam usaha mengejar tujuan operasi dan tujuan operasionalnya (Rukmana, 2006:16). Pengertian lain dikemukakan oleh F. Drucker dalam Scoderbeg (Sugiyono, 2003:23), menyatakan: "Effectiveness is the 
foundation of success and effectiveness is doing the right things. "Efektivitas merupakan landasan untuk mencapai sukses, dan dengan pekerjaan yang betul yang dikerjakan.".

Selanjutnya, Fremont E. Kas (Sugiyono, 2003:23), mengemukakan bahwa "Effectiveness is concerned with the accomplishment of esplicit or implicit goals". "Efektivitas berkenaan dengan derajat pencapaian tujuan baik secara eksplisit maupun implisit, yaitu seberapa jauh rencana dapat dilaksanakan dan seberapa jauh tujuan dapat tercapai”. Menurut Kamus Bahasa Indonesia (Hoetomo, 2005: 142), menyebutkan bahwa efektivitas mempunyai efek, pengaruh atau akibat; dapat membawa hasil; berhasil guna, mulai berlaku (tentang Undang-Undang).

Efektivitas dapat pula diartikan sebagai kondisi yang paling tepat dan baik, bilamana membandingkan penggunaan metode alat/sarana dengan kondisi yang nyata (Wiradihardja, 1991:25). Efektivitas menurut Joseph Prokopenko (Rukmana, 2006:15) yaitu suatu tingkatan terhadap mana tujuan dicapai. Selain itu, efektivitas menurut Martoyo (1994:4) adalah suatu kondisi atau keadaan, di mana dalam memilih tujuan yang hendak dicapai dan sarana atau peralatan yang digunakan, disertai dengan kemampuan yang dimiliki adalah tepat, sehingga tujuan yang diinginkan dapat dicapai dengan hasil yang memuaskan. Berdasarkan kedua pengertian tersebut dapat disimpulkan bahwa dalam pencapaian tujuan organisasi, sarana dan peralatan sangat diperlukan sehingga tujuan dapat tercapai dengan hasil yang baik.

Selain penggunaan sarana dan peralatan, aspek lain yang menentukan berhasil tidaknya suatu organisasi mencapai tujuannya adalah perilaku manusia, dalam hal ini perilaku aparat pelaksana. Perilaku aparat pelaksana dalam menjalankan tugas dan kewajibannya dengan positif dan mampu mengoptimalkan kemampuannya akan memiliki pengaruh yang positif pula terhadap penyelesaian pekerjaanya dan berakhir dengan kualitas keberhasilan pekerjaan yang baik. Hal tersebut sejalan sebagaimana dikemukakan oleh Friedlander dan Pickle serta Negandhi dan Reimann (Kasim, 1993:88) yang mengatakan bahwa perilaku dan ciri-ciri tertentu dari individu dan kelompok kecil dapat digunakan sebagai indikator efektivitas organisasi.

\section{Pengelolaan Dana Bantuan Operasional Sekolah (BOS)}

Mulai tahun 2007, pengelolaan program dana BOS antara Departemen Pendidikan Nasional dan Departemen Agama dilakukan secara terpisah. Beberapa hal yang sering diperhatikan dengan pemisahan pengelolaan ini antara lain:

a. Pendanaan program dana BOS untuk seluruh sekolah baik negeri maupun swasta (yang izin operasionalnya berasal dari Dinas Pendidikan )adalah tanggung jawab Departemen Pendidikan Nasional, sedangkan untuk madrasah, pondok pesantren salafiyah dan sekolah keagamaan lainnya (yang 
izin operasionalnya berasal dari Departemen Agama ) adalah tanggung jawab Departemen Agama.

b. Segala bentuk kegiatan yang mencakup proses pendataan, penyaluran dana, sosialisasi, pelaporan, monitoring dan penyelesaian kasus dilakukan oleh masing-masing departemen.

c. Penyaluran dana ke sekolah/madrasah.ponpes antara Departemen Pendidikan Nasional dan Departemen Agama harus diusahakan sesuai dengan jadwal.

Berdasarkan pengertian tersebut, dapat disimpulkan bahwa pengelolaan dana BOS antara Departemen agama dan Departemen Pendidikan mulai tahun 2007, dilakukan secara terpisah. Beberapa pemisahan tersebut, terdiri dari Pendanaan program dana BOS pendanaan program dana BO, Segala bentuk kegiatan yang mencakup proses pendataan, penyaluran dana, sosialisasi, pelaporan, monitoring dan penyelesaian kasus serta Penyaluran dana ke sekolah/madrasah.ponpes, segala bentuk kegiatan yang mencakup proses pendataan, penyaluran dana, sosialisasi, pelaporan, monitoring dan penyelesaian kasus serta Penyaluran dana ke sekolah/madrasah.ponpes antara Departemen Pendidikan Nasional dan Departemen Agama harus diusahakan sesuai dengan jadwal

Berdasarkan Buku Pedoman Bantuan Operasional Sekolah (BOS) dalam rangka wajib belajar 9 tahun, maka terdapat perbedaan tata tertib antara pengelola dana untuk tim manajemen BOS kabupaten/kota dengan tata tertib pengelolaan dana untuk sekolah. Perbedaan tersebut terletak pada tata tertib pengelolaan dana untuk Tim Manajemen BOS dimana disebutkan bahwa mengupayakan dana tambahan untuk kegiatan safeguarding kabupaten/kota masing-masing dari sumber APBD serta tidak diperkenankan mengkoordinir pembelian barang dan jasa dalam pemanfaatan dana BOS.

Menurut Buku Pedoman Bantuan Operasional Sekolah (BOS) dalam rangka wajib belajar 9 tahun, agar program Dana Bantuan Operasional Sekolah (BOS) dapat berjalan lancar dan transparan maka perlu dilakukan monitoring dan supervisi, pelaporan serta pengawasan secara efektif dan terpadu

\section{Efektivitas Penggunaan Dana Bantuan Operasional Sekolah (BOS)}

Berdasarkan tiga buah konsep yang digunakan untuk mengetahui efektivitas menurut Richard M. Steers, maka untuk mengetahui keefektifan penggunaan dana BOS dalam peningkatan mutu pendidikan di Madrasah Iftidayah Negeri Kabupaten Musi Banyuasin, hanya digunakan konsep perspektif sistem yang terdiri dari tiga komponen yaitu:

a. Input (masukan) merupakan langkah awal dalam melihat pelaksanaan dari kebijakan tentang program dana Bantuan Operasional Sekolah (BOS). Dalam input lebih ditekankan pada aktor pelaksana yang melaksanakan program tersebut yang dalam hal ini adalah sekolah yang diberi wewenang 
penuh dari pemerintah untuk mengelola Dana Bantuan Operasional Sekolah (BOS).

b. Proses, merupakan dasar dalam melaksanakan suatu pekerjaan. Dalam Proses melaksanakan program tersebut terdiri atas mekanisme pelaksanaan, yang terdiri dari:

1) Perencanaan program atau kegiatan yang akan dilaksanakan

2) Pengorganisasi denga pengurus organisasi sekolah (KOMITE)

3) Pelaksanaan

4) Pengawasan

c. Output merupakan hasil dari pelaksnaan suatu kebijakan seperti yang telah ditetapkan pada tujuan yang sebelumnya. Hasil dari pelaksanaan kebijakan tersebut merupakan tujuan yang hendak dicapai oleh pelaksnaan kebijakan tersebut, yang dapat berupa criteria tertentu sesuai dengan ketentuan yang berlaku.

Hasil Penelitian Penggunaan Dana Bantuan Operasional Sekolah (BOS) dalam Peningkatan Mutu Pendidikan pada MIN Lumpatan Kabupaten Banyuasin

Program dana Bantuan Operasional Sekolah (BOS) pada dasarnya merupakan bagian dari pada Program Kompensasi Pengurangan Subsidi Bahan Bakar Minyak (PKPS-BBM).

Dalam program ini salah satu sektor yang diutamakan adalah sektor pendidikan, yang diwujudkan dalam bentuk pemberian dana Bantuan Operasional Sekolah (BOS) yang dimulaiu sejak bulan Juli tahun 2005 sampai dengan sekarang yang telah menyelesaikan periode pertama yang berakhir pada Juni 2006. Pemberian dana Bantuan Operasional Sekolah (BOS) yang dialokasikan bagi SD/ MI/SDLB/ MTs/SMPLB negeri maupun swasta, pondok-pondok pesantren salafiyah serta sekolah keagamaan non-islam yang setara dengan SD dan SMP yang menyelenggarakan wajib belajar pendidikan dasaar yang selanjutnya disebut Sekolah, Program Bantuan Operasional Sekolah (BOS) bertujuan untuk memberikan bantuan kepada sekolah dalam rangka membebaskan iuran siswa, tetapi sekolah tetap mempertahankan mutu pelayanan pendidikan kepada masyarakat.

Pelaksanaan program Bantuan Operasional Sekolah (BOS) dilakukan oleh sekolah-sekolah yang menerima dana Bantuan Operasional Sekolah (BOS) tersebut secara umum dan khusus sekolah yang menjadi obyek penelitian penulis yakni MIN Lumpatan Kabupaten Banyuasin.

Dalam penggunaan dana Bantuan Operasional Sekolah (BOS) yang menjadi komponen input meliputi ;

\section{1) Kebutuhan Akan Tersedianya Dana}


Analisis ini bertujuan untuk melihat Kebutuhan Akan Tersedianya Dana . Data berasal dari analisis dokumen, hasil wawancara, serta hasil observasi di lapangan..

Akibat adanya krisis ekonomi yang melanda Indonesia yang dimulai tahun 1997 sampai dengan sekarang, serta adanya kenaikan harga BBM (Bahan Bakar Minyak) pada tahun 2005 yang lalu telah mengkibatkan naiknya harga pokok yang dalam hal ini adalah naiknya harga barang-barang kebutuhan sekolah sehingga membuat para orang tua siswa tidak mampu lagi membiayai anaknya untuk bersekolah dan sekolah pun tidak dapat menghindari naiknya beban biaya pendidikan yang diberikan kepada setiap siswanya. Akan sangat merugikan bangsa Indonesia tentunya apabila anak-anak muda penerus pembangunan Negara tidak dapat mendapatkan pendidikan yang layak. Hal ini akan berdampak pada kualitas sumber daya manusia Indonesia dimasa yang akan dating. Maka dengan adanya Program Kompensasi Pengurangan Subsidi Bahan Bakar Minyak (PKPS-BBM) yang didalam program ini salah satu sector yang diutamakan adalah sector pendidikan, yang diwujudkan dalam bentuk pemberian dana Bantuan Operasional Sekolah (BOS). Dimana program dana Bantuan Operasional Sekolah (BOS) ini bertujuan untuk memberikan bantuan kepada sekolah dalam rangka membebaskan iuran siswa, tetapi sekolah tetap mempertahankan mutu pelayanan pendidikan kepada masyarakat. Agar masyarakat dari golongan miskin mempunyai kesempatan menyekolahkan putraputrinya di sekolah-sekolah negeri yang berkualitas agar dapat bersaing dengan anak-anak dari golongan mampu lainnya. Hal ini pun salah satu upaya pemerintah dalam mengatasi masalah social dalam masyarakat indoensia yang hingga kini masih hisup dibawah garis kemiskinan.

MIN Lumpatan merupakan salah satu lembaga pemerintah yang berkewajiban memberikan pelayanan kepada masyarakat yaitu dalam bidang pendidikan. Semuanya itu tentunya mengharuskan sekolah melengkapi fasilitasfasilitas penunjang pendidikan, meningkatkan kualitas guru mengajardan tentunya meningkatkan mutu kelulusannya, yang tentunya membutuhkan anggaran kebutuhan dana yang besar seperti tertuang dalam Rencana Anggaran dan Pendapatan Belanja Sekolah (RAPBS).

Perndapat serupa juga dikemukakan oleh Guru MIN Lumpatan bernama Faizah pada tanggal 1 Maret 2010, diperoleh informasi sebagai berikut " Hal tersebut menjadi ketentuan yang ditetapkan dalam pengelolaam BOS dimana jumlah yang diajukan harus sama dengan yang akan diterima ".

Pendapat serupa juga dikemukan oleh Guru MIN Lumpatan bernama Ahmad Nawawi pada tanggal 1 Maret 2010 yang menyatakan bahwa "Jumlah dana yang diberikan tidak sesuai dengan anggaran sekolah karena jumlah dana yang diterima masih menggunakan data siswa yang 
lama (2007-2008) sedangkan pada tahun ini (2008-2009) siswa kami bertanbah jadi tidak sesuai. ".

Sedangkan pendapat Bendahara BOS MIN Limpatan mengenai kebutuhan akan tersedianya dana pada tanggal 1 Maret 2010, diperoleh informasi sebagai berikut " Dana yang kami terima pertama kali berjumlah Rp. 31.760.000,- untuk 3 bulan. Jumlah siswa 330 orang. Berarti jumlah persiswa pertiga bulan adalah Rp 96.250,-. yang berarti jumlah yang diajukan dengan yang diterima tidak sesuai".

Pernyataan serupa juga dikemukakan oleh Komite MIN Lumpatan bernama Anwar Bansyariah pada tanggal 1 Maret 2010, dan diperoleh informasi sebagai berikut " Besarnya dana BOS yang diterima sekolah dihitung berdasarkan jumlah siswa dikali dengan jumlah uang yang diterima siswa 3 bulan".

Berdasarkan seluruh hasil wawancara tersebut dapat diketahui bahwa pada Madrasah Ibtidaiyah Negeri (MIN) Lumpatan, kebutuhan akan tersedianya dana tidak sesuai dengan anggaran sekolah.

Berdasarkan hasil wawancara tersebut serta menurut hasil observasi penulis pada tanggal 3 Maret 2010, dapat disimpulkan bahwa pada dasarnya dalam melaksanakan dan memanfaatkan dana Bantuan Operasional Sekolah (BOS), pada MIN Lumpatan Kabupaten Musi Banyuasin kebutuhan akan tersedianya dana telah dilaksanakan dengan efektif/telah sesuai dengan anggaran sekolah.

\section{2) Tersedianya Sarana Dan Prasarana Untuk Menunjang Kegiatan Belajar Mengajar}

Analisis ini bertujuan untuk melihat sarana dan prasarana untuk menunjang kegiatan belajar mengajar. Data berasal dari analisis dokumen, hasil wawancara, serta hasil observasi.

Dalam melaksanakan suatu kegiatan belajar mengajar tentunya membutuhkan suatu sarana dan prasarana yang dapat menunjang kegiatan belajar mengajar tersebut. Hal tersebut dimaksudkan untuk meningkatkan kemampuan dari para siswa itu sendiri didalam menerima pelajaran yang diberikan oleh guru mereka. Dengan adanya sarana dan prasarana yang menunjang kegiatan belajar mengajar pada siswa diharapkan dapat belajar lebih giat lagi. Selain itu sarana dan prasarana juga sangan dibutuhkan dalam kegiatan pengelolaan administrasi sekolah.

Berdasarkan hasil wawancara dengan kepala MIN Lumpatan pada tanggal 1 Maret 2010 mengenai sarana dan prasarana untuk menunjang kegiatan belajar mengajar, diperolah informasi sebagai berikut " sejak adanya BOS sarana dan prasarana disekolah kami menjadi lebih baik. Walaupun masih ada yang kondisinya rusak". 
Pendapat serupa juga dikemukakan oleh guru MIN Lumpatan bernama Faizah pada tanggal 1 Maret 2010 dan diperoleh informasi sebagai berikut" Kondisi ruang pendidikan disekolahan kami belum seluruhnya baik karena ada dana BOS".

Sedangkan pernyataan guru MIN Lumpatan bernama Ahmad Nawawi pada tanggal 1 Maret 2010 mengenai sarana dan prasarana untuk menunjang kegiatan belajar mengajar, diperoleh informasi sebagai berikut " Sarana dan prasarana disekolah kami masih ada yang kondisinya masih kurang baik yaitu masih ada 3 (tiga) kelas yang kondisinyta kurang baik/rusak".

Merujuk dari hasil wawancara tersebut, dapat diketahui bahwa sejak adanya BOS, sarana dan prasarana di MIN Lumpatan Kabupaten Musi Banyuasin menjadi lebih baik dan sudah lengkap akan tetapi masih ada 3 (tiga) kelas yang kondisinya kurang baik/rusak.

Untuk lebih jelasnya berikut ini data mengenai sarana dan prasarana di Madrasah Ibtidayah Negeri Lumpatan Kabupaten Musi Banyuasin yang mendapatkan dana Bantuan Operasional Sekolah (BOS) di Kabupaten Musi Banyuasin, dapat dilihat pada tabel 2:

Tabel 3

Data Ruang Pendidikan dan Kondisinya Tahun 2009

\begin{tabular}{|c|c|c|c|c|c|c|}
\hline \multirow{2}{*}{ No } & \multirow{2}{*}{ Nama Ruang } & \multirow{2}{*}{$\begin{array}{c}\begin{array}{c}\text { Rincian } \\
\text { Ruang }\end{array} \\
\text { Jumlah }\end{array}$} & \multicolumn{3}{|c|}{ Kondisi Ruang } & \multirow{2}{*}{ Ket } \\
\hline & & & Baik & Sedano & Rusak & \\
\hline 1. & Kelas & 14 & $\mathrm{~V}$ & & $\mathrm{~V}$ & 11 (baik), 3 (rusak) \\
\hline 2. & Ruang guru & 1 & $\mathrm{~V}$ & & & \\
\hline 3. & Perpustakaan & 1 & $\bar{V}$ & & & \\
\hline 4. & Ruang Kepala Sekolah & 1 & $\mathrm{~V}$ & & & \\
\hline 5. & Lapangan & 1 & V & & & \\
\hline 6. & Ruang UKS & 1 & & $\mathrm{~V}$ & & \\
\hline
\end{tabular}

Sumber: Kantor Tata Usaha Madrasah Ibtidayah Negeri Lumpatan Kabupaten Musi Banyuasin tahun 2009

Berdasarkan tabel tersebut dapat dilihat bahwa kondisi masing-masing ruang dan sarana pendidikan di Madrasah Ibtidayah Negeri Lumpatan Kabupaten Musi Banyuasin, semua kondisinya baik hanya ruang UKS dengan kondisi sedang dan ruang kelas masih ada yang berkondisi rusak. Hal ini menunjukkan bahwa adanya ketidaksesuaian antara dana BOS yang dikeluarkan dengan kondisi saat ini, sebab dalam BOS terdapat alokasi dana perawatan/pemeliharaan. Kondisi ini dikhawatirkan dapat menghambat dalam peningkatan mutu pendidikan di sekolah

Pendapat Bendahara BOS MIN Lumpatan mengenai sarana dan prasarana untuk menunjang kegiatan belajar mengajar pada tanggal 1 Maret 2010, diperoleh informasi sebagai berikut " Sarana dan prasarana dalam kondisi baik semua walaupun masih ada kelas yang kondisinya rusak".

Pernyataan serupa juga dikemukakan oleh Komite sekolah MIN Lumpatan bernama Bapak Anwar Bansyariah pada tanggal 1 Maret 2010, dan 
diperoleh informasi sebagai berikut " Kondisi alat-alat dan ruang kelas dalam kondisi baik., hanya 3 (tiga) kelas yang kondisinya rusak dan 1 (satu) kelas kondisinya sedang".

Berdasarkan hasil wawancara tersebut serta menurut hasil observasi penulis pada tanggal 3 Maret 2010, dapat disimpulakan bahwa pada dasarnya dalam melaksanakan dan memanfaatkan dana Bantuan Operasional Sekolah (BOS) pada MIN Lumpatan Kabupaten Musi Banyuasin, kondisi sarana dan prasarana dalam menunjang kegiatan belajar mengajar belum efektif . Hal ini dapat dilihat dari masih ada ruang kelas yang kondisinya rusak Kondisi demikian menunjukkan bahwa adanya ketidaksesuaian antara dana BOS yang dikeluarkan dengan kondisi saat ini, sebab dalam BOS terdapat alokasi dana perawatan/pemeliharaan. Kondisi ini dikhawatirkan dapat menghambat dalam peningkatan mutu pendidikan di sekolah

\section{3) Sumber Daya Manusia atau Aktor Pelaksana}

Analisis ini bertujuan untuk melihat sumber daya manusia atau aktor pelaksana. Data berasal dari analisis dokumen, hasil wawancara, dan hasil observasi.

Dalam pemanfaatan/penggunaan dana Bantuan Operasional Sekolah (BOS) tentunya harus didukung dengan adanya sumber daya manusia atau actor pelaksana yang nantinya akan melaksanakan program dana Bantuan Operasional Sekolah (BOS) di sekolah-sekolah yang menjadi obyek dalam penelitian ini. Aktor pelaksana tersebut antara lain kepala sekolah, bendahara BOS, pegawai tata usaha, dan juga guru-guru yang dikut sertakan dalam pelaksnaannya nanti. Dengan adanya kerjasama yang baik, maka diharapkan pemanfaatan dana tersbut dapat berjalan dengan baik pula.

Sedangkan pernyataan guru MIN Lumpatan bernama Ahmad Nawawi pada tanggal 1 Maret 2010 mengenai sarana dan prasarana untuk menunjang kegiatan belajar mengajar, diperoleh informasi sebagai berikut " tingkat pendidikan seluruh guru ditempat kami rata-rata berpendirikan sampai D-3 tapi ada juga S-1".

\section{1) Perencanaan Kegiatan Atau Program Dan Besarnya Dana Yang Akan Digunakan Untuk BOS}

Analisis ini bertujuan untuk melihat Perencanaan kegiatan atau program dan besarnya dana yang akan digunakan untuk kegiatan atau program tersebut. Data berasal dari analisis dokumen dan hasil wawancara, serta hasil observasi.

Dalam setiap proses pemanfaatan suatu dana terlebih dahulu melalui suatu proses penyusunan rencana. Hal ini penting karena didalam perencanaan merupakan suatu penentuan dan perhitungan terhdap apa yang akan dilaksanakan. Dengan adanya suatu perencanaan yang baik maka tujuan dari apa yang diharapkan nantinya dapat tercapai, perencanaan juga sangat membantu dalam pelaksanaannya nantinya. 
Penyusunan rencana pemanfaatan dana Batuan Operasional Sekolah (BOS) dilakukan oleh kepala MIN Lumpatan dan wakil kepala MIN Lumpatan selaku bendahara dana Batuan Operasional Sekolah (BOS). Dalam penyusunan rencana tersebut, juga melibatkan tata usaha sekolah, dan para dewan guru karena para dewan guru tersebutlah yang paling mengetahui apa yang dibutuhkan dalam menunjang kegiatan belaja mengajar. Setelah mengetahui kebutuhan yang diperlukan dan dilengkapi, maka rencana pemanfaatan dana tersebut disusun dan dibagi kedalam beberapa kegiatan atau program yang nantinya akan dilaksanakan

Sebelum semua rencana tersebut disahkan sebagai program sekolah, terlebih dahulu program dan rencana kerja tersebut dirapatkan dengan para pengurus KOMITE sekolah sebagai salah satu bentuk pengawasan yang dilakukan oleh masyarakat (wali murid) terhadap penggunaan dana Batuan Operasional Sekolah (BOS).

Dana Batuan Operasional Sekolah (BOS) harus menjadi salah satu sumber pembiayaan dalam Rencana Anggaran Pendapatan dan Belanja Sekolah (RAPBS). Dana Batuan Operasional Sekolah (BOS) sendiri pada dasarnya hanya boleh digunakan oleh sekolah sesuai dengan kebutuhan operasional sekolah. Sebagaimana telah diatur dalam Buku Pedoman Bantuan Operasional Sekolah (BOS) dalam rangka wajib belajar 9 tahun, tujuan utama penggunaan dana Bantuan Operasional Sekolah (BOS), yaitu :tidak boleh menyimpang dari 13 item seperti yang terdapat pada halaman 37.

Dimana semua bentuk pengeluaran dana utama penggunaan dana Bantuan Operasional Sekolah (BOS), yaitu oleh sekolah dikenakan Pajak Penghasilan ( $\mathrm{PPh}$ ) serta Pajak Pertambahan Nili (PPN) sesuai dengan peraturan yang ada, kecuali untuk biaya transportasi bagi siswa miskin tidak dikenakan pajak. Oleh karena itu, sekolah yang menjadi obyek dalam penelitian ini haruslah menggunakan dana utama penggunaan dana Bantuan Operasional Sekolah (BOS), yaitu tersebut sesuai dengan Buku Pedoman Bantuan Operasional Sekolah (BOS) dalam rangka wajib belajar 9 tahun seperti tersebut diatas.

Besarnya dana yang dibutuhkan oleh sekolah dalam menunjang kegiatan atau program yang telah direncanakan sebelumnya yang dalam hal ini adalah jumlah dana yang dibutuhkan untuk keperluan penunjang belajar mengajar sesuai dengan Buku Pedoman Bantuan Operasional Sekolah (BOS) dalam rangka wajib belajar 9 tahun, jumlahnya bersifat tetap artinya tidak sesuai dengan kebutuhan sekolah.

Responden yang menjawab bahwa besarnya dana yang akan digunakan untuk BOS sudah sesuai dengan kebutuhan sekolah dikemukakan oleh kepala sekolah, bendahara BOS dan Komite sekolah pada MIN Lumpatan pada tanggal 1 Maret 2010, adapun alasan dari hasil wawancara dengan beberapa responden adalah sebagai berikut 
" Semua kebutuhan sekolah terpenuhi sesuai dengan dana yang ada terutama dalam proses kebutuhan belajar mengajar ". (Kepala MIN Lumpatan)

" Karena ada BOS, kabutuhan sekolah terpenuhi ". (Bendahara BOS MIN Lumpatan)

"Sementara itu walaupun pada dasarnya jumlah tersebut belum cukup, tetapi kami menyesuaikan dengan jumlah uang yang ada. Jadi dengan jumlah tersebut kami cukup-cukupkan sana ". (Komite MIN Lumpatan).

Merujuk dari hasil wawancara tersebut, dapat diketahui bahwa pada MIN Lumpatan semua kebutuhan sekolah terpenuhi sesuai dengan dana yang ada terutama dalam proses kebutuhan belajar mengajar, walaupun pada dasarnya jumlah tersebut belum cukup, tetapi kami menyesuaikan dengan jumlah uang yang ada. Jadi dengan jumlah tersebut kami cukup-cukupkan saja

Pernyataan responden yang menyatakan bahwa besarnya dana yang akan digunakan untuk BOS belum sesuai dengan kebutuhan sekolah akan dikemukakan oleh guru MIN Lumpatan bernama Faizah pada tanggal 1 Maret 2010, adapun alasan dari hasil wawancara dengan beberapa responden adalah sebagai berikut " dana cukup untuk keperluan siswa tapi untuk operasional masih kurang".

Pendapata serupa juga dikemukakan oleh guru MIN Lumpatan bernama Ahmad Nawawi pada tanggal 1 Maret 2010, sebagai berikut " Dana BOS yang diterima tidak sebanding dengan kebutuhan sekolah terutama untuk kegiatan siswa yang semakin meningkat dan membuthkan biaya yang cukup besar ".

\section{2) Koordinasi Antara Pihak Sekolah Dengan Pengurus KOMITE}

Analisis ini bertujuan untuk melihat Koordinasi antara Pihak Sekolah dengan Pengurus KOMITE. Data berasal dari analisis dokumen dan hasil wawancara, serta hasil observasi.

Setelah pihak sekolah menyusun rencana kegiatan atau program yang akan dilaksanakan beserta dengan jumlah dana yang dibutuhkan, maka tahap selanjutnya adalah koordinasi antara pihak sekolah dengan pengurus KOMITE. Koordinasi dalam pemanfaatan dana Bantuan Operasional Sekolah (BOS) adalah koordinasi antara pihak sekolah dengan pengurus organisasi sekolah yaitu KOMITE sekolah. Koordinasi yang dilakukan adalah tidak lain merupakan suatu koordinasi intern antara pihak sekolah dengan pengurus KOMITE sekolah yaitu Ketua KOMITE sekolah. Setelah ketua KOMITE sekolah menyetujui semua kegiatan atau program yang telah disusun, maka pihak sekolah dapat langsung melaksanakan kegiatan atau program tersebut.

Hasil wawancara dengan responden pada tanggal 1 Maret 2010 mengenai koordinasi antara pihak sekolah dengan KOMITE sekolah sudah dilakukan oleh sekolah akan dikemukakan oleh kepala sekolah MIN Lumpatan, adapun dari hasil wawancara tersebut adalah sebagai berikut " RAPBS dibuat 
setiap tahun yang ditandatangani oleh KOMITE sekolah dan untuk SPJ ditandatangani oleh KOMITE dalam setiap tahun ".

\section{3) Kegiatan Penggunaan Dana Bantuan Operasional Sekolah dalam Memenuhi Kebutuhan Sekolah}

Analisis ini bertujuan untuk melihat Kegiatan Penggunaan Dana Bantuan Operasional Sekolah dalam Memenuhi Kebutuhan Sekolah. Data berasal dari analisis dokumen dan hasil wawancara, serta hasil observasi.

Setelah pihak sekolah menyusun rencana kegiatan atau program beserta dengan jumlah dana yang dibutuhkan dan telah mendapatkan persetujuan dari KOMITE sekolah maka tahap selanjutnya adalah pelaksanaan. Pada pelaksanaan pihak sekolah mulai melaksanakan semua kegiatan atau program yang telah disusun sebelumnya.

Sebagaimana telah diatur dalam Buku Pedoman Bantuan Operasional Sekolah (BOS) dalam rangka wajib belajar 9 tahun, tujuan utama penggunaan dana Bantuan Operasional Sekolah (BOS), yaitu :

Dana Bantuan Operasional Sekolah (BOS) yang diterima oleh sekolah dialokasikan untuk membayarkan uang dalam rangka penerimaan siswa baru: biaya pendaftaran, pengadaan formulir, administrasi pendaftaran, dan pendaftaran ulang, serta kegiatan lain yang berkaitan langsung dengan kegiatan tersebut. Sehingga siswa-siswa baru tidak perlu mengeluarkan uang lagi.

Dana Bantuan Operasional Sekolah (BOS) yang diterima oleh sekolah dialokasikan untuk Pembelian buku teks pelajaran (diluar buku yang telah dibeli dari dana BOS buku) dan buku referensi untuk dikoleksi di perpustakaan. Dengan demikian diharapkan perpustakaan dapat dijasikan sebagai tempat memperoleh buku pelajaran baik itu untuk guru maupun untuk murid dalam mempelajari suatu ilmu pengetahuan. Diharapkan para murid tidak lagi harus membeli buku pelajaran yang diluar harganya relative mahal, mereka dapat saja meminjam buku yang dimiliki oleh perpustakaan sekolah dengan gratis.

Dana Bantuan Operasional Sekolah (BOS) yang diterima oleh sekolah dialokasikan untuk Pembiayaan kegiatan pembelajaran remedial, pembelajaran pengayaan, olahraga, kesenian, karya ilmiah remaja, pramuka, palang merah remaja dan sejenisnya. Sehingga diharapkan dengan adanya kegiatan tersebut, wawasan dan pengetahuan siswa-siswa menjadi lebih luas dan pintar serta nilai siswa yang dibawah standar dapat diperbaiki..

Program Dana Bantuan Operasional Sekolah (BOS) yang diterima oleh sekolah dialokasikan untuk Pembiayaan ulangan harian, ulangan umum, ujian sekolah/madrasah/ponpes dan laporan hasil belajar siswa. Alokasi dana pada bagian ini ternagi menjadi 4 (empat) sub bagian yang masing-masing sub bagian dibagi kembali sesuai dengan kebutuhannya. Keempat bagian tersebut adalah sebagai berikut 
(1) ulangan harian terdiri atas insentif panitia, pembuatan soal praktek dan tertulis, dan pengetikan soal tertulis

(2) ulangan umum

(3) ujian sekolah/madrasah/ponpes

(4) laporan hasil belajar siswa

Program Dana Bantuan Operasional Sekolah (BOS) yang diterima oleh sekolah dialokasikan untuk Pembelian bahan-bahan habis pakai. Pembelian bahan-bahan habis pakai tersebut adalah buku tulis, kapur tulis, pensil, bahan pratikum. Kegiatan pembelian bahan-bahan habis pakai ini dilaksanakan oleh masing-masing bagian yang berkepentingan seperti para dewan guru sebagai alat penunjang belajar mengajar dikelas, dan para pegawai tata usaha sekolah.

Program Dana Bantuan Operasional Sekolah (BOS) yang diterima oleh sekolah dialokasikan untuk Pembiayaan langganan daya dan jasa. Pembayaran biaya daya dan jasa dimaksud disini adalah bantuan bayar telepon, bantuan bayar listrik sekolah, bantuan bayar air PDAM. Dana BOS tersebut dikeluarkan tiap 3 (tiga) bulan sekali.

Program Dana Bantuan Operasional Sekolah (BOS) yang diterima oleh sekolah dialokasikan untuk Pembiayaan perawatan sekolah/madrasah/ponpes: pengecetan; perbaikan atap bocor; perbaikan pintu dan jendela; perbaikan meubeler, perbaikan sanitasi sekolah dan perawatan fasilitas sekolah lainnya.

Dana Bantuan Operasional Sekolah (BOS) yang diterima oleh sekolah dialokasikan untuk Pembayaran honorarium bulanan guru honorer dan tenaga kependidikan honorer. Pembayaran gaji guru honor dana tenaga kependidikan honor dilaksanakan oleh sekolah sesuai dengan pencairan dana Bantuan Operasional Sekolah (BOS) itu sendiri, yang jumlah besaran tiap-tiap orang berbeda sesuai dengan spesifikasi pekerjaannya di sekolah. Besarnya jumlah gaji masing-masing guru dan tenaga kependidikan honor telah ditetapkan sebelumnya dan telah dimasukkan dalam Rencana Anggaran Pendapatan dan Belanja Sekolah (RAPBS)

Program Dana Bantuan Operasional Sekolah (BOS) yang diterima oleh sekolah dialokasikan untuk Pengembangan profesi guru; pelatihan, KKG/MGMP dan KKKS/MKKS. Maksudnya adalah guru akan diberikan pendidikan dan pelatihan supaya wawasan dan pengetahuan guru bertambah.

Dana Bantuan Operasional Sekolah (BOS) yang diterima oleh sekolah dialokasikan untuk Pemberian bantuan biaya transportasi bagi siswa miskin yang menghadapi masalah biaya transport dari dan ke sekolah/madrasah/ponpes. Pemberian bantuan biaya transportasi kepada siswa miskin diberikan sesuai dengan aturan yang telah ditetapkan. Seperti yang kita ketahui bersama, semenjak naiknya harga BBM (Bahan Bakar Minyak) mengakibatkan naiknya ongkos bus atau angkutan umum yang tentunya sangat memberatkan para orang tua murid yang kurang mampu tersebut. 
Dalam menetapkan alokasi dana BOS tiap sekolah/madrasah/ponpes perlu dipertimbangkan bahwa dalam satu tahun anggaran terdapat dua periode tahun pelajaran yang berbeda, sehingga perlu acuan sebagai berikut: Pengelolaan dana BOS dilaksanakan dalam dua periode yaitu periode Januari-Juni2007 didasarkan pada jumlah siswa tahun pelajaran 2006/2007 dan periode JuliDesember 2007 didasarkan pada data jumlah tahun pelajaran 2007/2008. Oleh karena itu diperlukan biaya untuk pembiayaan pengelolaan dana BOS.

\section{4) Pengawasan terhadap Kegiatan Penggunaan Dana Bantuan Operasional Sekolah (BOS)}

Analisis ini bertujuan untuk melihat Pengawasan terhadap Kegiatan Penggunaan Dana Bantuan Operasional Sekolah (BOS). Data berasal dari analisis dokumen dan hasil wawancara, serta hasil observasi.

Tahapan akhir dari pelaksanaan dana Bantuan Operasional Sekolah (BOS) adalah pengawasan. Pengawasan itu sendiri secara intern dilaksanakan oleh pengurus KOMITE sekolah dan wali murid, dan secara ekstern dilaksanakan oleh aparat pemerintah yakni dari Departemen Agama, Badan Pemeriksa Keuangan Pusat (BPKP), Inspektorat Departemen Agama RI, dan juga dilaksanakan oleh Lembaga Swadaya Masyarakat (LSM) yang berkepentingan terhadap perkembangan dunia pendidikan Bangsa Indonesia.

Berdasarkan hasil wawancara dengan kepala sekolah MIN Lumpatan pada tanggal 2 Maret 2010 mengenai pengawasan terhadap kegiatan penggunaan dana BOS, diperoleh informasi sebagai berikut " Penggunaan dana BOS disekolah mendapat pengawasan dari pihak terkait yaitu dari Kantor Wilayah Departemen Agama Kabupaten Musi Banyuasin".

Pendapat serupa juga dikemukakan oleh Salah satu guru MIN Lumpatan pada tanggal 2 Maret 2010, dan diperoleh informasi sebagai berikut " untuk mengantisipasi terjadinya penyelewengan dana BOS perlu adanya sinergi kemitraan pengawasan antara Komisi IV yang membidangi pendidikan harus bekerja sama dengan pihak Depag".

Hasil wawancara tersebut menunjukkan bahwa Penggunaan dana BOS di MIN Lumpatan sudah mendapat pengawasan dari pihak terkait yaitu dari Kantor Wilayah Departemen Agama Kabupaten Musi Banyuasin

Pernyataan Bendahara BOS MIN Lumpatan pada tanggal 2 Maret 2010 mengenai pengawasan terhadap penggunaan dana BOS, diperoleh informasi sebagai berikut

" dalam hal monitoring/pengawasan dilakukan oleh tim manajemen BOS yaitu Depag Kabupaten Musi Banyuasin artinya apabila pihak Depag menemukan ada permasalahan maka dengan demikian Depag akan segera menyelesaikan masalah tersebut ". 
Hasil wawancara dengan Komite sekolah MTSN mengenai pengawasan terhadap penggunaan dana Bantuan Operasional Sekolah (BOS) pada tanggal 20 Juni 2009, diperoleh informasi sebagai berikut " selalu diperiksa oleh Inspektorat Jenderal Departemen Agama "

Merujuk dari hasil wawancara dengan beberapa responden tersebut, dapat diketahui bahwa pada MIN Lumpatan, penggunaan dana BOS disekolah mendapat pengawasan dari pihak terkait yaitu dari Kanwil Departemen Agama Kabupaten Musi Banyuasi. Untuk mengantisipasi terjadinya penyelewengan dana BOS perlu adanya sinergi kemitraan pengawasan antara Komisi IV yang membidangi pendidikan harus bekerja sama dengan pihak Depag. Dalam hal monitoring/pengawasan dilakukan oleh tim manajemen BOS yaitu Depag Kabupaten Musi Banyuasin artinya apabila pihak Depag menemukan ada permasalahan maka dengan demikian Depag Kabupaten akan segera menyelesaikan masalah tersebut

Pengawasan sangat penting sekali dilakukan sebab uang yang diberikan itu jumlahnya tidak sedikit, artinya pengawasan yang ketat harus dilakukan oleh pihak-pihak yang terkait secara terus menurus. Departemen Agama sebagai instansi pemerintah yang paling bertanggung jawab atas pengeluaran dan pelaporan tentang penggunaan dana Bantuan Operasional Sekolah (BOS) khusus Madrasah Ibtidayah Negeri (MIN) Lumpatan secara rutin telah melaksananakan pemantauan dan pemeriksaan setiap akhir periode (triwulan) pengeluaran atau pencaiaran dana Bantuan Operasional Sekolah (BOS).

Berdasarkan hasil wawancara tersebut serta menurut hasil observasi penulis pada tanggal 20 Juni 2009, dapat disimpulkan bahwa kegiatan pengawasan terhadap penggunaan dana Bantuan Operasional Sekolah (BOS) telah berjalan dengan efektif/baik. Sebagai masukan kiranya hal ini perlu dipertahankan dan untuk lebih ditingkatkan untuk menjagaagar program ini benar-benar berjalan sebagaimana mestinya.

\section{Peningkatan Mutu Pendidikan Sekolah}

Analisis ini bertujuan untuk dan hasil wawancara, penyebaran kuasioner serta hasil observasi. melihat Peningkatan Mutu Pendidikan Sekolah. Data berasal dari analisis dokumen

Hasil wawancara dengan Kepala madrasah, Guru dan komite sekolah MIN Lumpatan mengenai peningkatan mutu pendidikan disekolah pada tanggal 2 Maret 2010 diperoleh informasi sebagai berikut

" nilai rata-rata ujian nasional cenderung meningkat dan prestasi non akademik lebih baik ". (Kepala MIN Lumpatan)

" ada motivasi untuk belajar lebih giat dan mempunyai motivasi yang tinggi sehingga jumlah siswa yang lulus dapat meningkat". (Guru MIN Lumpatan)

" Ada peningkatan prestasi belajar dan jumlah kelulusan karena adanya bantuan dana sehingga dengan tercukupinya kebutuhan misalnya buku-buku 
menambah semangat siswa untuk belajar ". (Bendahara BOS MIN Lumpatan)

" Bagi siswa yang mendapat bantuan meringankan beban dan lebih banyak memperhatikan pelajaran dari pada memikirkan biaya walaupun baru sedikit ". (Komite sekolah MIN Lumpatan)

Merujuk dari hasil wawancara tersebut, dapat diketahui bahwa peningkatan mutu pendidikan di Madrasah Ibtidayah Negeri (MIN) Lumpatan sudah berjalan dengan efektif dan dapat meningkatkan jumlah kelulusan siswa dan prestasi belajar siswa-siswi di madrsah tersebut.

\section{Analisis Jumlah kelulusan siswa}

Analisis ini bertujuan untuk melihat jumlah keluusan siswa. Data berasal dari analisis dokumen dan hasil wawancara dengan kepala madrasah, guru dan bendahara BOS di MIN Lumpatan serta hasil observasi

Hasil wawancara dengan kepala MIN Lumpatan pada tanggal 2 Maret 2010 mengenai jumlah kelulusan siswa dan diperoleh informasi sebagai berikut dengan adanya penggunaan dana BOS di madrasah kami, salah satu dampak yang dirasakan yaitu siswa diterima di Madrasah Tsanawiyah (M'Ts) Negeri melalui Tes.

Pendapat serupa juga dikemukakan oleh salah satu guru di MIN Lumpatan pada tanggl 2 Maret 2010, dan diperoleh informasi sebagai berikut salah satu dampak dari penggunaan dana BOS di sekolah kami, yaitu siswa diterima di Madrasah Tsanawiyah (MTs) Negeri melalui Tes.

Merujuk dari hasil wawancara tersebut, dapat diketahui bahwa salah satu dampak dari penggunaan dana BOS di MIN Lumpatan Kabupaten Musi Banyuasin yaitu siswa diterima di SMP/Madrasah Tsanawiyah (MTs) Negeri melalui Tes.

Untuk lebih jelas lagi mengenai jumlah siswa MIN Lumpatan Kelas VI yang diterima di SMP/MTs negeri melalui tes dari tahun 2007-2009, dapat dilihat pada tabel 4 sebagai berikut

\section{Tabel 4}

Jumlah Siswa MIN Lumpatan Kelas VI Yang Diterima Di SMP/MTs Negeri Melalui Tes Tahun 2007-2009

\begin{tabular}{|c|c|c|}
\hline \multirow{2}{*}{ Tahun } & \multicolumn{2}{|c|}{ Jumlah siswa MIN Lumpatan } \\
\cline { 2 - 3 } & Jumlah siswa kelas VI & Jumlah siswa yang diterima di SMP/MTs \\
& & Negeri \\
\hline 2007 & 70 & 40 \\
2008 & 73 & 48 \\
2009 & 70 & 54 \\
\hline
\end{tabular}

Sumber MIN Lumpatan Kabupaten Musi Banyuasin

Merujuk dari tabel tersebut, dapat diketahui bahwa jumlah siswa kelas VI MIN Lumpatan yang diterima di SMP/MTs negeri melalui tes pada tiap tahunnya mengalami peningkatan. Hal ini bisa dilihat dari, tahun 2007 jumlah siswa kelas VI yaitu sebanayk 67 siswa, dengan jumlah siswa yang diterima di 
SMP Negeri yaitu sebanyak 40 siswa atau sekitar 59,70\%. Tahun 2008 jumlah siswa kelas VI yaitu sebanyak 70 siswa, dengan jumlah siswa yang diterima di SMP negeri melalui tes yaitu sebanyak 48 siswa atau sekitar 68,57\%. Sedangkan untuk tahun 2009, jumlah siswa kelas VI yaitu sebanyak 73 siswa, dengan jumlah siswa yang diterima di SMP negeri melalui tes yaitu sebanyak 54 siswa atau sekitar $73,97 \%$.

Berdasarkan hasil wawancara, dokumen serta hasil observasi pada tanggal 4 Maret 2010, dapat disimpulkan bahwa dengan adanya penggunaan dana BOS diMIN Lumpatan Kabupaten Musi Banyuasin, bisa meningkatakan mutu pendidikan terutama bisa meningkatakan jumlah siswa kelas VI yang bisa diterima di SMP/MTs negeri melalui tes tiap tahun.

\section{Analisis Tingkat Prestasi Siswa (Rata-Rata Indeks Prestasi Siswa Setelah Program BOS).}

Analisis ini bertujuan untuk melihat Analisis Tingkat Prestasi Siswa (Rata-Rata Indeks Prestasi Siswa Setelah Program BOS. Data berasal dari analisis dokumen dan hasil wawancara dengan kepala sekolah, guru, bendahara serta komite sekolah di MIN Lumpatan serta hasil observasi

Pendapat serupa juga dikemukakan oleh komite sekolah pada tanggal 2 Maret 2010, dan diperoleh informasi sebagai berikut " dengan adanya BOS ada peningkatan karena adanya bantuan dana sehingga dengan tercukupinya kebutuhan misalnya buku-buku menambah semangat siswa untuk belajar sehingga nilai rata-rata ujian nasional cenderung meningkat dan prestasi non akademik lebih baik dari tahun ketahun ".

Menurut hasil wawancara tersebut, dapat diketahui bahwa dengan adanya dana BOS dapat meringankan beban dan dan siswa lebih banyak memperhatikan pelajaran dari pada memikirkan biaya walaupun baru sedikit sehingga mereka termotivasi untuk belajar lebih giat sehingga nilai rata-rata ujian nasional cenderung meningkat dan prestasi non akademik lebih baik dari tahun ketahun.

\section{Tercapainya Tujuan Utama Program Dana Bantuan Operasional Sekolah (BOS)}

Analisis ini bertujuan untuk melihat Tercapainya Tujuan Utama Program Dana Bantuan Operasional Sekolah (BOS). Data berasal dari analisis dokumen dan hasil wawancara, serta hasil observasi.

Program dana Bantuan Operasional Sekolah (BOS) bertujuan untuk membebaskan biaya pendidikan bagi siswa tidak mampu dan meringankan bagi siswa yang lain, agar mereka memperoleh layanan pendidikan dasar yang lebih bermutu sampai tamat dalam rangka penuntasan wajib belajar pendidikan dasar 9 tahun. Melalui BOS peserta didik tingkat pendidikan dasar akan dibebaskan dari segala macam bentuk biaya operasional sekolah 
Responden yang menjawab bahwa Peningkatan mutu pendidikan disekolah sudah berjalan dengan baik dan ada peningkatan prestasi belajar siswasiswi disekolahnya akan dijawab oleh kepala MIN Lumpatan, guru, bendahara BOS dan Komite sekolah pada tanggal 2 Maret 2010, adapun dari hasil wawancara dengan beberapa responden adalah sebagai berikut

" Tujuan program BOS sudah dijelaskan melalui buku petunjuk/buku panduanBOS, maupun melalui sosialisasi Depag kota atau provinsi". (Kepala MIN Lumpatan)

" dana BOS bertujuan untuk membebaskan biaya pendidikan bagi siswa tidak mampu dan meringankan bagi siswa yang lain agar mereka memperoleh layanan pendidkan dasar yang lebih bermutu samapai tamat dalam rangka pemerataan wajib belajar 9 tahun ". (Guru MIN Lumpatan)

" tujuan dana BOS adalah untuk meringankan beban operasional sekolah dan untuk meringankan beban siswa yang masu sekolah ". (Bendahara BOS MIN Lumpatan)

" pengelola/bendahara BOS telah membaca petunjuk penggunaan dana BOS tersebut dan bendahara BOS sudah pernah mengikuti penataran mengenai pengelolaan dana BOS ". (Komite MIN Lumpatan).

Berdasarkan hasil wawancara tersebut serta menurut hasil observasi penulis pada tanggal 4 Maret 2010, dapat disimpulkan bahwa pihak sekolah tidak lagi memungut iuran dari KOMITE sekolah (yang dahulu kita kenal dengan nama iuran BP3) yang selama ini merupakan salah satu sumber pendapatan sekolah. Artinya para wali murid tidak lagi dibebankan dengan biaya operasional sekolah lagi.

\section{Analisis Hasil Pembahasan}

Analisis indikator dalam penelitian yang menyangkut efektifitas pengnggunaan Dana BOS dalam meningkatkan Mutu Pendidikan di MIN Lumpatan Kabupaten Musi Banyuasin adalah sebagai berikut:

\begin{tabular}{|c|c|c|}
\hline Indikator & MIN & Keterangan \\
\hline $\begin{array}{l}\text { 1. Input, indikatornya } \\
\text { adalah: } \\
\text { a. Kebutuhan akan tersediannya dana } \\
\text { b. Sumber daya material yaitu tersedianya } \\
\text { sarana dan prasarana } \\
\text { c. Sumber daya manusia yaitu dewan guru } \\
\text { dan para pegawai tata usaha } \\
\text { 2. Proses, indikatornya adalah: } \\
\text { a. Perencanaan kegiatan dan besarnya dana } \\
\text { yang akan digunakan untuk kegiatan } \\
\text { bersebut Koordinasi antara pihsk sekolah dengan } \\
\text { pengurus komite } \\
\text { c. Kegiatan penggunaan dan BOS dalam } \\
\text { memenuhi kebutuhan sekolah }\end{array}$ & $\begin{array}{l}\text { Efektif } \\
\text { Belum } \\
\text { Efektif } \\
\text { Efektif }\end{array}$ & $\begin{array}{l}\text { kondisi sarana dan prasarana dalam menunjang } \\
\text { kegiatan belajar mengajar belum efektif. Hal ini } \\
\text { dapat dilihat dari masih ada ruang kelas yang } \\
\text { kondisinya rusak }\end{array}$ \\
\hline
\end{tabular}




\begin{tabular}{|ll|l|l|}
\hline d. Pengawasan terhadap penggunaan dana & Efektif & \\
3. $\begin{array}{l}\text { Output, indikatornya adalah: } \\
\text { a. Peningkatan mutu pendidikan di sekolah } \\
\text { b. Tercapainya tujuan utama penggunaan dana } \\
\text { BOS }\end{array}$ & Efektif & Efektif & \\
\hline
\end{tabular}

Sedangkan 1 (satu) indikator yang belum dilaksanakan dengan efektif yaitu Sumber daya material yaitu tersedianya sarana dan prasarana. Hal ini dapat dilihat dari masih ada ruang kelas yang kondisinya rusak Kondisi demikian menunjukkan bahwa adanya ketidaksesuaian antara dana BOS yang dikeluarkan dengan kondisi saat ini, sebab dalam BOS terdapat alokasi dana perawatan/pemeliharaan. Kondisi ini dikhawatirkan dapat menghambat dalam peningkatan mutu pendidikan di sekolah

Adanya indicator yang tidak efektif menunjukkan bahwa antara teori yang ada, tidak sesuai dengan kenyataan dilapangan, yang seharusnya seluruh indicator yang ada harus terlaksana dengan efektif agar tujuan penggunaaan dana bantuan operasional sekolah (bos) dapat berjalan sebagaimana yang diharapkan.

\section{Kesimpulan}

Berdasarkan hasil penelitian yang telah diuraikan disimpulkan bahwa pengelolaan dana Bantuan Operasional pada MIN Lumpatan Kab. Musi Banyuasin telah berjalan dengan efektif yaitu, Kebutuhan akan tersedianya dana, sarana dan prasarana penunjang kegiatan belajar mengajar, Sumber daya manusia, Perencanaan kegiatan atau program dan besarnya dana yang akan digunakan untuk kegiatran atau program tersebut, kegiatan penggunaan dana bantuan operasional sekolah dalam memenuhi kebutuhan sekolah, Koordinasi antara pihak sekolah dengan KOMITE, pengawasan terhadap penggunaan dana Bantuan Operasional Sekolah (BOS), Peningkatan mutu pendidikan, Tercapainya tujuan penggunaan dana BOS serta Tercapainya Tujuan Utama Program dana BOS.

Walaupun banyak media massa yang mengekpose permasalahan dana Bantuan Operasional Sekolah (BOS), wajar saja karena dana BOS melayani ratusan ribu siswa-siswa yang ada di Kota Sekayu bahkan di Sumatera Selatan, tentunya ada pro dan kontra, tapi jangan lupa bahwa dana BOS hanyalah meringankan biaya sekolah bukan penggatisan seluruh dana sekolah.

Berdasarkan hasil pembahasan dan analisis hasil pembahasan, Efektivitas pengnggunaan dana Bantuan Operasional Sekolah (BOS) dalam meningkatkan mutu pendidikan secara maksimal dapat dilihat melalui perspektif sistem yaitu

Berdasarkan tiga buah konsep yang digunakan untuk mengetahui efektivitas menurut Richard M. Steers, maka untuk mengetahui keefektifan penggunaan dana BOS dalam meningkatkan mutu pendidikan pada MIN Lumpatan, hanya digunakan konsep perspektif sistem yang terdiri dari tiga komponen yaitu: 
1. Input (masukan) merupakan langkah awal dalam melihat pelaksanaan dari kebijakan tentang program dana Bantuan Operasional Sekolah (BOS). Dalam input lebih ditekankan pada aktor pelaksana yang melaksanakan program tersebut yang dalam hal ini adalah sekolah yang diberi wewenang penuh dari pemerintah untuk mengelola Dana Bantuan Operasional Sekolah (BOS).

2. Proses, merupakan dasar dalam melaksanakan suatu pekerjaan. Dalam Proses melaksanakan program tersebut terdiri atas mekanisme pelaksanaan, yang terdiri dari:

a. Perencanaan program atau kegiatan yang akan dilaksanakan

b. Pengorganisasi denga pengurus organisasi sekolah (KOMITE)

c. Pelaksanaan kegiatan penggunaan dana BOS

d. Pengawasan terhadap kegiatan penggunaan dana BOS

3. Output merupakan hasil dari pelaksnaan suatu kebijakan seperti yang telah ditetapkan pada tujuan yang sebelumnya. Hasil dari pelaksanaan kebijakan tersebut merupakan tujuan yang hendak dicapai oleh pelaksnaan kebijakan tersebut, yang dapat berupa kriteria tertentu sesuai dengan ketentuan yang berlaku.

Berdasarkan analisis hasil pembahasan, penggunaan dana BOs telah dilaksanakan dengan efektif. Adanya indikator yang tidak efektif menunjukkan bahwa antara teori yang ada, tidak sesuai dengan kenyataan dilapangan, yang seharusnya seluruh indicator yang ada harus terlaksana dengan efektif agar tujuan penggunaaan dana bantuan operasional sekolah (BOS) dapat berjalan sebagaimana yang diharapkan.

\section{Saran}

Setelah melihat pengelolaan dana Bantuan Operasional Sekolah (BOS), maka ada beberapa hal yang perlu diperhatikan dalam pengelolaan dana Bantuan Operasional Sekolah (BOS) adalah

1. Hendaknya pihak sekolah lebih terbuka, transparan dan akuntabilitas terhadap penggunaan ddana Bantuan Operasional Sekolah (BOS). Sehingga diharapkan besarnya dana yang akan digunakan untuk kegiatan tersebut dapat memenuhi kebutuhan sekolah.

2. Pengawasan harus lebih ditingkatkan untuk menjaga agar program ini benarbenar berjalan sebagaimana mestinya.

3. Kinerja para pelaksana BOS juga lebih ditingkatkan lagi dalam rangka meningkatkan akuntabilitas dan profesionalisme pelaksanaannya.

4. Sosialisasi tentang pengelolaan dana Bantuan Operasional Sekolah (BOS) terus ditingkatkan sampai ke madrasah-madrasah, sehingga tujuan dana Bantuan Operasional Sekolah (BOS) dapat tercapai sesuai dengan yang diharapkan oleh pemerintah. 
204 | TADBIR : Jurnal Studi Manajemen Pendidikan, Vol. 2, No. 2, Desember 2018

5. Pengelolaan dana Bantuan Operasional Sekolah (BOS) pada MIN Lumpatan yang telah berjalan dengan efektif, disarankan semua ini dapat dipertahankan dan kalau bisa dapat ditingkatkan lagi, sehingga betul-betul dapat menyentuh anak-anak yang tidak mampu dan dapat meringankan beban bagi siswa yang lain. 


\section{Daftar Pustaka}

Arikunto, Suharsimi. 1996. Prosedur Penelitian Suatu pendekatan Praktek Edisi Revisi IV. Jakarta: Rineka Cipta

Danumihardja, Mintarsih. 2004. Manajemen Keuangan Sekolah. Jakarta: Uhamka Press

Gibson, Ivancevei dan Donnelly. 1996. Organisasi (Perilaku, Struktur, Proses). Jakarta: Erlangga

Hoetomo. 2005. Kamus Lengkap Bahasa Indonesia. Surabaya: Mitra Pelajar

Ibrahim, Amin. 2004. Pokok-Pokok Analisis Kebijakan Publik. Bandung: Mandar Maju

Kasim, Azhari. 1993. Pengukuran Efektivitas dalam Organisasi. Jakarta: LPFEUI

Keban, Yeremias. 2004. Enam Dimensi Strategis Administrasi Publik. Yogyakarta: Gava Media

Martoyo, Susilo. 1994. Manajemen Sumber daya Manusia. Edisi ketiga. Yogyakarta: BPFE

Moleong, Lexy, J. 2005. Metode Penelitian Kualitatif. Jakarta: PT Rinesa Rasdakarsa Munir, dkk., 2004. Kebijakan dan Manajemen Keuangan Daerah. Yogyakarta: YPAPI

Rukmana, Nana. 2006. Strategic Planning for Educational Management Model Manajemen Pendidikan Berbasis Kemitraan). Bandung: Alfabeta

Singarimbun, Masri dan Sofyan Effendi. 1995. Metode Penelitian Survey. Jakarta: LP3ES

Sinungan, Muchdarsyah. 2000. Produktivitas Apa dan Bagaimana. Jakarta: Bumi Aksara

Sugiyono. 2003. Metode Penelitian Administrasi. Bandung: CV. Alfabeta

Sutarto. 2000. Dasar-Dasar Organisasi. Jakarta: Gajah Mada: University Press

Steers, Richard. 1996. Efektivitas Organisasi (Kaidah Tingkah Laku). Jakarta: LP3ES

Wiradiharja, Moeftie. 1987. Pedoman Administrasi Umum (Bidang Tata Persuratan). Jakarta: Balai Pustaka

Referensi-referensi:

Panduan Bantuan Operasional Sekolah dalam Rangka Wajib Belajar 9 Tahun 2009

Hasil Monitoring dan evaluasi yang telah dilakukan (Laporan Kegiatan PKPSBBM Bidang Pendidikan Tahun 2008

Surat Edaran Dikdasmen Depdiknas ke Dinas seluruh Indonesia No.133/C3/LL/2009 
206 | TADBIR : Jurnal Studi Manajemen Pendidikan, Vol. 2, No. 2, Desember 2018

This page belongs to the TADBIR : Jurnal Studi Manajemen Pendidikan

TADBIR : Jurnal Studi Manajemen Pendidikan vol. 2 , no. 6, Desember 2018

STAIN Curup - Bengkulu | p-ISSN 2580-3581; e-ISSN 2580-5037 